by Naresh Chandra Pant ${ }^{*}$, Preeti Singh ${ }^{1}$ and A.K. Jain ${ }^{2}$

\title{
A Re-look at the Himalayan metamorphism
}

\author{
${ }^{1}$ Department of Geology, University of Delhi, Delhi-11007; *E-mail: pantnc@gmail.com \\ ${ }^{2}$ CSIR-Central Building Research Institute, Roorkee-247667
}

(Received : 15/04/2019; Revised accepted : 07/08/2019)

https://doi.org/10.18814/epiiugs/2020/020023

Regional metamorphic rocks preserve records of geodynamic evolution of orogenic belts. The Himalaya represents an evolving mountain belt with a complex geological history and is considered here as a composite of Trans-Himalaya and the Himalaya per se and the intervening Indus-Tsangpo Suture Zone. Each of these three tectonic domains is evaluated in the context of their metamorphic evolution. An episodic evolution is inferred and described. The beginning of the Himalayan orogeny is ascribed to the Cretaceous initiation of the suturing of the 'island arc' rocks with the Asian block, followed by underthrusting of the Indian block $~ 57$ Ma ago. Differences in metamorphism of underthrust and overthrust blocks are reflected in their P-T-t evolution. The exhumation along the strike length was unequal with significantly higher exhumation rates along the syntaxes. The anatectic melt produced at the time of the Tertiary age Himalayan metamorphism got emplaced within the Himalaya as well as within the Trans-Himalaya, possibly through crustal-scale faults such as the Karakoram fault.

\section{Introduction}

Our ability to interpret evidences preserved in metamorphic rocks is critical to understanding their evolutionary history and to constraining models of orogenesis (Brown, 2007). The Himalayan metamorphic rocks, therefore, may be considered as the "black box" of the Himalayan orogeny. It is interesting to compare the Himalayan metamorphism with older orogens for their evolutionary history (Dewey and Burke, 1973; Avouac and Tapponnier, 1993; Larsen et al. 1999; Yin and Harrison, 2000). There is also a general consensus that this "not yet complete" orogeny resulted from a multi-stage collision with the subduction of the Tethyan oceanic crust followed by the continent-continent (Indian and Eurasian Plates) collision (Dewey and Burke, 1973; Le Fort, 1975; Searle, 1988, 1996; Kohn, 2014). There are some other striking differences in the metamorphic characters of the older orogens and the Himalaya. For example, as the orogeny involves closing of a basin (inter- or intra-continental), a significant component of the metamorphosed rocks in older orogeny are those which were autochthonous. Khondalites in the Eastern Ghats Mobile Belt (EGMB) and Alwar and Ajabgarh metasediments in the Delhi Fold Belt illustrate this observation. Other than the UHP eclogite assemblages, there appears to be very scanty report of the Himalayan or Tethys basin rocks metamorphosed during the Himalayan orogeny.

A view also exists that there was significant early Paleozoic tectonism in the Himalaya (Gansser, 1964; LeFort, 1983; Thakur, 1993; Valdiya, 1995; Srikantia and Bhargava, 1983 ). Considering early Paleozoic deformation of the Cambro-Ordovician granites (Stocklin, 1980) in Nepal, regional metamorphism of Greater Himalayan rocks (e.g. deformation of metapelites hosting the $488 \mathrm{Ma}$ Kinnaur Kailash granite, Marquer et al. 2000; Chawla et al. 2000) and signatures of uplift during early Paleozoic (e.g. Garzanti et al. 1986) as well as significant changes in sedimentation in the Tethyan sequence (e.g. Bordet et al. 1971), Gehrels et al. (2003) proposed that the Himalayan orogen originated during early Paleozoic and the phenomena of thrusting, crustal thickening, metamorphism and magmatism associated with this was different from that of the Tertiary time.

There are few reports of pre-Himalayan metamorphism (Miller et al. 2000). Using overprinted contact metamorphic assemblages on the Paleoproterozoic Jeori' Wangtu granite gneiss, Pant et al. (2006) demonstrated the presence of pre $\sim 1800 \mathrm{Ma}$ low-grade regional metamorphism in the Jeori-Wangtu Tectonic window in NW Himalaya. An early Paleozoic metamorphic and magmatic event is also reported from several sections of the Lesser Himalaya (e.g. Pakistan-Baig et al. 1988; Himachal Himalaya-Miller et al. 2001; Kundu et al. 2008; Kumaun Himalaya-Oliver et al. 1995; Joshi et al. 1994; Schärer and Allegre, 1983).

During the last three decades there have been some excellent reviews of the Himalayan metamorphism (e.g. Verma, 1989; Kohn, 2014). The salient features of the Himalayan metamorphism from the most recent review by Kohn (2014) may be summarised as follows:

- Lesser Himalayan Sequence (LHS) - Greater Himalayan Sequence (GHS) Tethyan Himalayan Sequence (THS) assemblage, can be considered a metamorphic "sandwich," in which low-grade THS and LHS rocks bound the intervening high-grade GHS rocks. The outliers are generally of lower metamorphic grade than the hinterland sections.

- Lateral continuity of metamorphic grades of the LHS-GHSTHS units exceeds a distance of 2,000 km. Similarly, inversion of metamorphic grade is continuous from the LHS through 
the GHS, along the strike length of 2,000 km. Kohn (2014) also mentions telescoping or truncating of metamorphic grades from the top of the GHS through the base of the THS by the South Tibet Detachment System (STDS).

- Along-strike consistency of rock types and structures allows age-equivalent parts of the orogen to be compared.

- Presence of Ultra High Pressure (UHP) assemblages in NW Himalaya and in NE Nepal. Geographically restricted occurrences of unusually high-grade metamorphic rocks along syntaxes (High P rocks and granulites in the vicinity of Nanga Parbat syntaxis in the west and granulites and cordierite+spinel and other granulite assemblages as well as young leucogranites in the core of Namche Barwa massif).

The restricted exposures of metamorphic rocks are shown in Figure 1 as the Himalayan Metamorphic Belt.

From north to south, three geological segments, namely the TransHimalayan metamorphics (THM), the Indus-Tsangpo Suture Zone metamorphics (ITSZM) and the Himalayan metamorphics (HM) can be differentiated (Fig.2) and preserve distinct metamorphic signatures and, together, can be used to discuss the Himalayan orogen in a comprehensive manner. The present paper describes the metamorphic evaluation of the Himalaya evaluating these three segments or tectonic domains.

\section{Metamorphism along three different segments}

In the following sections, metamorphic events along three different geological zones, viz, Trans-Himalaya, Indus-Tsangpo Suture Zone and Himalaya proper have been discussed via different well studied sections, along various geographic locations from west to east.

\section{Trans-Himalayan Metamorphism}

\section{Regional and Tectonic Setting}

Major lithotectonic units of the Trans-Himalayan zone from the Ladakh include the Shyok Formation and the Pangong Metamorphic Complex (PMC) along with the Indus Formation and the Ladakh granite gneiss (Figs. 1, 2). The ITSZ demarcates the boundary between Himalaya and Trans-Himalayan zone, while the Shyok Suture Zone (SSZ) separates the Karakoram Metamorphic Complex from the Ladakh granite gneisses and the Karakoram Thrust crosses between ITSZ and SSZ.

The Himalayan orogenesis is associated with pre-collisional as well as post-collisional processes. Post-syncollisional metamorphism is generally considered limited to the Himalaya, i.e. south of the suture zone and the pre-collisional features/metamorphism is related to the Trans (Himalayan batholiths and Ladakh) Kohistan Arc towards north of the suture zone. The ITSZ separates the Indian continental part from the Asian continent (Searle and Owen, 1999).

\section{Metamorphism along Trans-Himalayan Zone}

High grade metamorphic rocks have been reported from the Karakoram Metamorphic Complex (KMC), i.e. the exposure between Karakoram Batholith (in north) and SSZ (in south) along Karakoram thrust (Fig. 2). KMC mainly comprises of two distinct metamorphic belt: the Tangtse Group characterized by high-grade sillimanite-Kfeldspar-bearing garnetiferous schist and gneiss, amphibolite, hornblende granite gneiss and leucogranite as well as localized granulite facies metamorphics in the Pangong Range (Rolland and Pecher 2001). Presence of granulite facies rocks indicate that the KSZ might have accommodated lateral extrusion of Tibet at least at crustal or even a lithospheric-scale shear zone (Rolland et al. 2009). Another metamorphic unit is Pangong group: comprised of mainly slate, mica

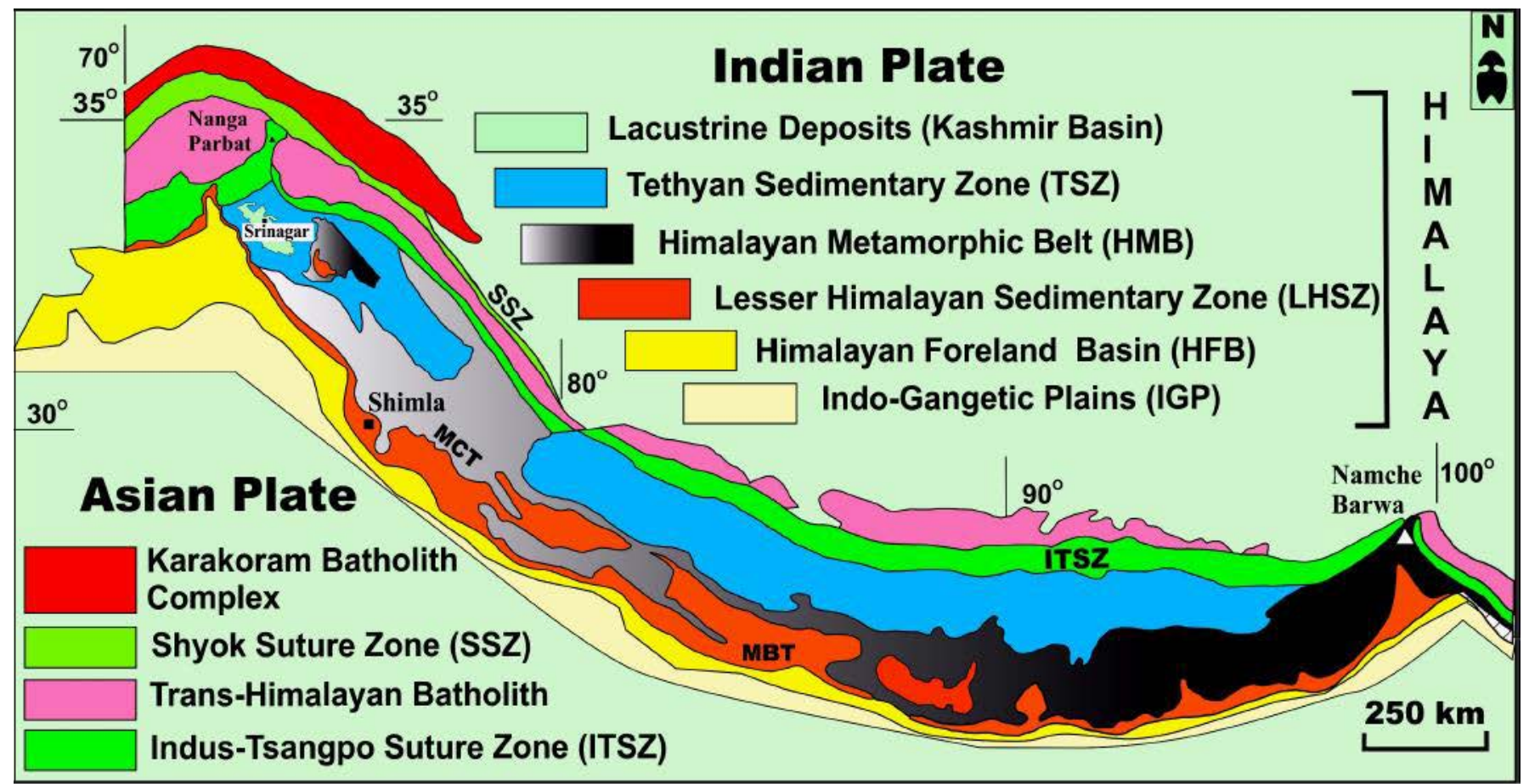

Figure 1. Map showing Himalayan Metamorphic belt. 


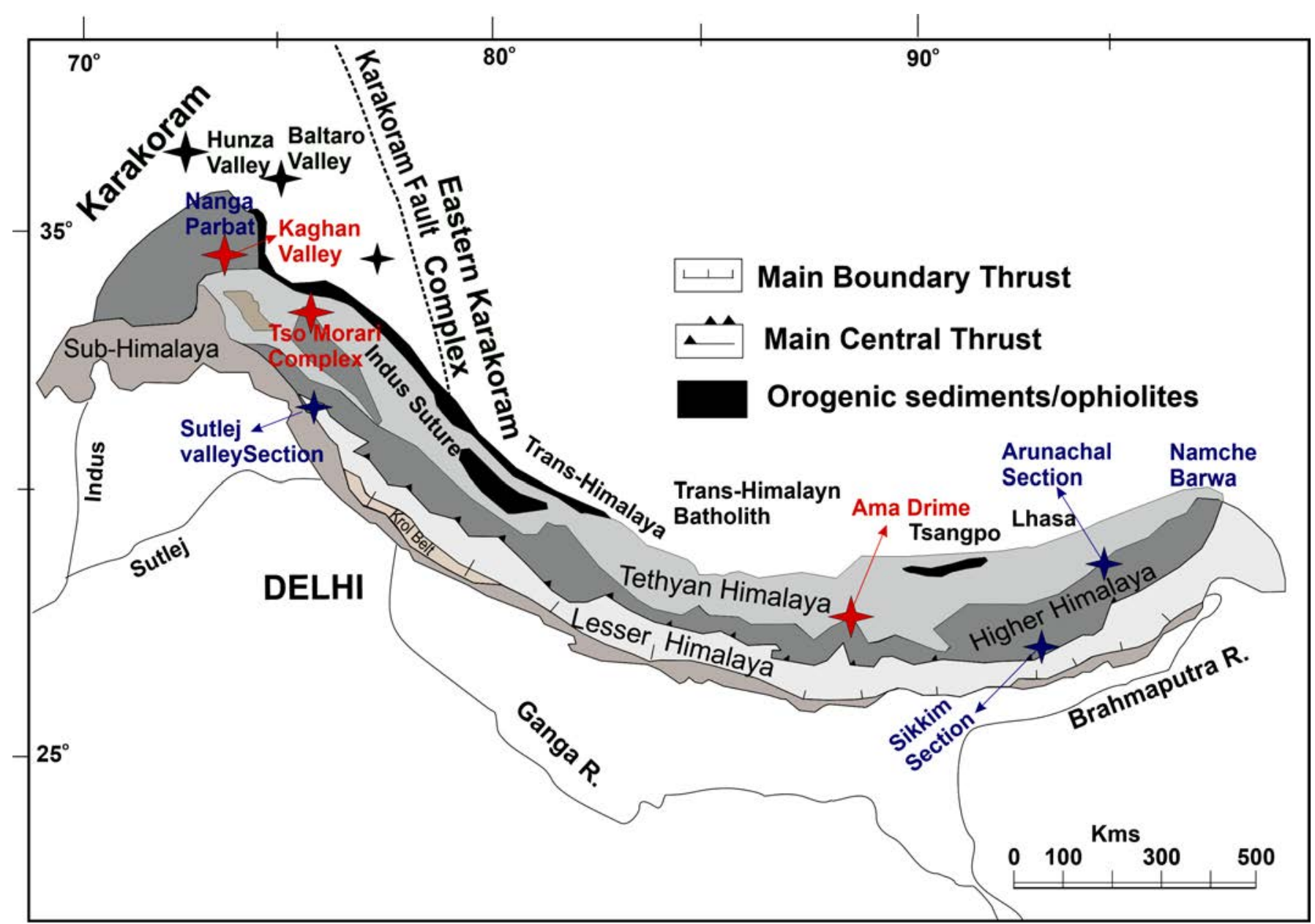

Figure 2. A geological map showing subdivisions of the Himalaya (modified after Gansser,1964). Different metamorphic units in the TransHimalayan, Himalayan and Suture Zone (high pressure and ultrahigh pressure metamorphic rocks) have been marked (see Table 1 for references); blue star represent sections from Himalayan metamorphic zone (Sutlej valley, Sikkim valley, Arunachal Himalayan section and Namche-Barwa \& Nanga-Parbat syntaxial zone); red colored star represent metamorphic units from the Suture Zone/HP-UHP rock units (Kaghan valley, Tso Morari Complex (TMC) and Ama Drime section) and black colored stars represent Trans-Himalayan metamorphic units (Baltaroo and Hunza Valley and Eastern Karakoram Complex comprises of Pangong Metamorphic Complex, Pangong Transpressional zone and Nubra valley section).

schist, greenschist/amphibolite and marble, calc-silicate and a band of mylonitized granite gneiss. Metamorphism varies from biotite grade of middle greenschist to sillimanite-muscovite subfacies of the middle amphibolite facies within this belt (Jain and Singh 2008).

Two sections have been studied in detail by Palin et al. (2012) for metamorphic events in this zone of Trans-Himalayan region:

\section{1) The Hunza Valley (W) and the Baltoro region (SE) (Western Section) (Fig. 2)}

In general, the metamorphic rocks exposed in the Baltoro region preserves the metamorphic sequence from chlorite to sillimanite-grade. At places, low-pressure high-temperature metamorphism is documented by the presence of andalusite metapelites. The regional metamorphic conditions in the garnet-kyanite schists have been calculated as $\sim 650-700^{\circ} \mathrm{C}$ temperature and 6-10 kbar pressure with ages attributed as $28.0 \pm 0.5 \mathrm{Ma}$ (Fraser et al. 2001) and $22.0 \pm 0.3$ Ma (Searle et al. 2010).

Subduction of the Tethys Ocean beneath the southern Asian margin during the Cretaceous led to the emplacement of the Hunza
Plutonic Unit of the Karakoram Batholith whose various components have crystallization ages ranging between c. 105 and c. $95 \mathrm{Ma}$, and associated with the Tethyan subduction-related formation of the Hunza Plutonic Unit (HPU) of the Karakoram Batholith.

In the Hunza valley the metamorphic rocks are bound to the north by the subduction-related HPU of the Karakoram Batholith and comprises of two metamorphic units: K-feldspar-bearing migmatites of upper sillimanite zone and a muscovite-bearing metapelites of lower sillimanite zone. A kyanite grade overprint of sillimanite grade rocks with $\mathrm{P}-\mathrm{T}$ conditions of $\sim 7.8 \mathrm{kbar}, 645^{\circ} \mathrm{C}$ with an age estimate of 28.2 $\pm 0.8 \mathrm{Ma}$ has been reported from the Hunza valley (associated with the ongoing India-Asia collision). Similar metamorphic conditions have also been reported from the Baltoro region at $\sim 21 \mathrm{Ma}$. An andalusite-grade contact metamorphic event has also been reported at $105.5 \pm 0.8 \mathrm{Ma}$, at unknown P-T conditions (Palin et al. 2012). These workers combine the field, metamorphic and age data to show that there is a southward younging of metamorphic units from Hunza Plutonic Unit which is dated to be Cretaceous. A U-Pb age of $\sim 63 \mathrm{Ma}$ for metamorphic monazites from sillimanite gneisses in the Hunza Valley and $\sim 44 \mathrm{Ma}$ from a kyanite-grade schist from the Baltoro 
region have been reported by Fraser et al. 2001. The youngest grade metamorphism of graphitic garnet-staurolite bearing assemblage (Hunza valley) is constrained between 16 and 9 Ma (Fraser et al. 2001; Palin et al. 2012). A sillimanite-K-feldspar-grade metamorphism and partial melting record have been reported from Dassu and Bullah gneiss domes (Baltoro unit) (Rolland et al., 2001; Searle et al., 2010), dated at $5.4 \pm 0.2 \mathrm{Ma}$ (U-Pb monazite; Fraser et al., 2001).

\section{2) Eastern section}

Detailed metamorphic studies in the eastern Karakoram zone have been carried out by several workers though only in isolated sections (Searle et al. 2010; Thanh et al. 2011; Wallis et al. 2013, 2014). In this region, the Karakoram Fault Zone (KFZ) cuts through mediumhigh grade metamorphic rocks of the Karakoram terrane and is associated with migmatite and granite.Geologically, the Karakoram Metamorphic Complex in the east can be linked with the Metamorphic Complex in the Baltoro and the Hunza regions. It is composed of four sub-units: Pangong Transpressional Zone (PTZ); Pangong Metamorphic Complex (PMC); Nubra Formation and Saser Formations from SE to NW (Fig. 2).

Prograde metamorphism of the PTZ is recorded by $\mathrm{Grt}+\mathrm{Ky}+\mathrm{St}$ metapelites with P-Tconditions of $\sim 680^{\circ} \mathrm{C}$ and $8.5 \mathrm{kbar}$ based on compositional zoning of $\mathrm{Mn}$ and Fe in garnet (Thanh et al. 2011). Peak metamorphic stage of granulite facies was calculated for the PMC along Karakoram fault as $\sim 800^{\circ} \mathrm{C}$ and c. $5.5 \mathrm{kbar}$ (assemblage $\mathrm{Cpx}+\mathrm{Prg}+\mathrm{Scp}+\mathrm{Spl}+\mathrm{Qtz}+\mathrm{Pl})($ Rolland and Pecher, 2001). It has been suggested that $\mathrm{Mn}$-rich garnet core formed during prograde metamorphism in a subduction zone followed by abrupt exhumation, during early collision of the Ladakh arc and Karakoram block, while, the Fe-rich garnet rims were attributed to the subsequent India-Asia continental collision that subducted the metamorphic rocks to a midcrustal level.On the basis of theassemblages, a geothermal gradient of $\sim 22^{\circ} \mathrm{C} / \mathrm{km}$ has been calculated and attributed to the crustal thickening following the India-Asia collision.

The PMC comprises of metapelites from staurolite to sillimanite grade with metamorphic conditions of $\sim 585-605^{\circ} \mathrm{C}$ temperature at $\sim 6$ 7 kbar pressure attained prior to initiation of the KFZ. Amphibolite grade migmatization in the Pangong Transpressional Zone is inferred to have occurred under a higher geothermal gradient of $36 \pm 7^{\circ} \mathrm{C} / \mathrm{km}$. The U-Pb monazite age of $108.0 \pm 0.6 \mathrm{Ma}$ from sillimanite-bearing gneiss in the Pangong strand of the suture zone is correlated with the ages of the Hunza granite-granodiorite batholith, and the K2 orthogneiss in northern Pakistan (Streule et al. 2009). It indicates that high-grade metamorphism along the Pangong Metamorphic Complex occurred possibly during collision and accretion of the Kohistan arc and the Asian plate. Based on the petrology and compositional characteristics of the metamorphic rocks, it is suggested that the Karakoram fault acted as an exhumation route of the metamorphosed supracrustal rocks including PMC and the leucogranites. This rapid exhumation was responsible for the rapid cooling of the rocks from greenschist facies temperatures (ca. $500^{\circ} \mathrm{C}$ ).

Nubra Formation comprises of metavolcanic rocks show peak metamorphism in the greenschist facies which is characterised by the growth of epidote and chlorite (Wallis et al. 2013). Metapelite from the Saser Formation experienced peak temperature of $\sim 660^{\circ} \mathrm{C}$.

\section{Metamorphism along Indus-Tsangpo Suture Zone/High-Pressure and Ultra-High Pressure Metamorphism(HPM and UHPM)}

\section{Regional Tectonic setting}

The first report of eclogite from the Himalaya dates back to 1953 , when Berthelesen (1953), described the geology of the remote and then nearly inaccessible terrain of the Rupshu district in the southeastern part of the state of Jammu and Kashmir. Detailed regional geologic description was provided later on by Srikantia and Bhargava (1978) which has remained so far the basic source of information on the local geology. A decade later, in the valley of the Kaghan river, about $200 \mathrm{~km}$ west of the Tso Morari, eclogites were reported (Pognante and Spencer, 1991) and later on in the adjacent Neelum valley as well. After another decade a fourth locality, Ama Drime, in Nepal became known (Groppo et al. 2007) (Fig. 2). The metamorphic path of these UHPM zone has significant bearing on defining the nature of subduction (e.g. angle of subduction, P-T-t path of the subducted block and recovery) (e.g. Klootwijk et al. 1992; Kaneko et al. 2003; Leech et al. 2005; Epard and Steck, 2008; Singh et al. 2013).

Indus Suture Zone (ISZ) is a several hundred kilometer long zone that demarcates the northernmost boundary of the Indian subcontinent following the late Cretaceous-early Tertiary closure of the Neo-Tethys and consists of obducted fragments of the former Neo-Tethyan oceanic lithosphere. It defines the collision between the Indian plate and the Ladakh arc and consists of components of Trans-Himalayan zone, Neo-Tethyan ocean floor and parts of the Indian Plate. The southernmost unit of the Indus Suture Zone consists of Zildat ophiolitic mélange that thrusts over the Tso Morari Crystallines and, in turn, is overlain by the Nidar ophiolites in the NW Himalaya (Fig. 2); this ophiolitic belt consists of thrust slices of basic volcanic rocks, deformed garnet schist with lenses of serpentinite and limestone. As a whole, the mélange belt consists of basic schists, limestones, serpentinites, glaucophane-garnet schist and amygdaloidal basalts.Some of these lithologies represents metamorphosed ocean floor (Honegger et al. 1982, 1986; Ahmad et al. 1996). The western ophiolite belt of Pakistan consists of pyroxenite, gabbro and sheeted dikes deformed and metamorphosed at conditions varying from granulite to greenschistfacies. Many gabbro in Nidar and Karzog Ophiolites samples consist of metamorphic assemblage of hornblende and albitic plagioclase (Mahéo et al. 2004).

Shyok Suture Zone (SSZ) extends in NW-SE direction and lies between the Ladakh Plutonic Complex and the Karakoram Zone in the north. This unit can broadly be divided into the Shyok Group consisting of basic volcanic along with chert, shale, quartzite, limestone and the Shyok Ophiolites. The ophiolites comprise of mélange consisting of serpentinite and pillow lavas of Eocene age. The high-grade metamorphic rocks have also been reported towards south of suture zone as klippe overlying an ophiolitic tectonic mélange $(\sim \mathrm{P}-\mathrm{T}=12$ $\mathrm{kb} / 850^{\circ} \mathrm{C}$, of $123-128 \mathrm{Ma}$ age) that is inferred to be the metamorphic sole under the ophiolite massifs that formed contemporaneously with the ophiolitic crust (Guilmette et al. 2009, 2012).

Metamorphic studies/path of the UHP rock from the Tso-Morari Crystallines, NW Ladakh cover three metamorphic stages : pre-UHP 
stage (epidote-blueschist facies regime) that marks possibly the beginning of subduction process associated with the convergence of the Indian and Asian plates, followed by UHP stage (UHP eclogite facies regime) marked by continued subduction taking the continental and the oceanic crusts to a minimum depth of about $130 \mathrm{~km}$ and the post-UHP stage (amphibolite followed by greenschistfacies regime) marked by the buoyant rise of the subducting rocks along the same shear zones that were active during the subduction(Figs. 2, 3b). Also, it has been suggested that final exhumation of the Tso Morari Complex (including eclogites of all levels) took place simultaneously along with the exhumation of the Central Crystallines i.e., post Mid-Miocene (Liou et al. 2004).

\section{Himalayan Metamorphism (HM)}

\section{Regional and Tectonic Setting}

To the south of the ITSZ there lies a Proterozoic-Phanerozoic and younger succession of rocks of the Indian Plate as well as those of the Tethys basin that have been folded, thrusted, and shortened by several hundred kilometres after India-Asia collision. Systematic metamorphic studies in the Himalaya for past several decades by many workers (e.g. Gansser, 1964; Dewey and Burke, 1973; Hodges, 2000, 2003; Le Fort, 1996; Verma, 1989, 2003; Yin, 2000, 2006; Searle, 1988, 2003; Kohn, 2014; Jain et al. 2016; O’Brien et al. 2018) have brought out new data as well as new inferences. However, most of these studies are on the Central Crystallines and on the ultra-high pressure metamorphism with relatively low emphasis on the low grade transformations in LHS and other sectors. The inverted Barrovian metamorphic sequence, considered as one of the most prominent as well as intriguing feature of the Himalayan Metamorphic Complex, can be seen along the length of the orogeny (along MCT), from Nanga Parbat in the west to Namche Barwa in Arunachal in the east (Figs. 1, 2). The MCT has been active ( 22Ma) for a long time and also generated heat (frictional or otherwise) to affect recrystallization.

All these processes led to regional Barrovian facies metamorphism in the Himalayan rocks along the length of the Greater Himalaya. Kyanite- and sillimanite-grade metamorphic rocks are also present along the two syntaxial regions in the far NW (Nanga Parbat syntaxis, Pakistan) and far NE (Namcha Barwa syntaxis) (Zeitleir et al. 1993; Su et al. 2012; Searle et al. 2015).

The Himalayan Metamorphism can be marked by two events: (i) Tertiary regional metamorphism, followed by obduction of ophiolites along suture zone and emplacement of granitoids, and (ii) a lower grade metamorphism (Verma, 1989). High grade metamorphism is prominent in the central crystalline zone and in metamorphosed Tethyan Himalayan succession. Within the thrust sheet of lesser Himalaya inverted metamorphism can be seen along many sections (Verma, 1999, Harrison, 1998; Yin and Harrison, 2000; Hodges, 2000).

\section{NW Himalaya-Sutlej section (Fig. 2)}

The Himalayan Crystalline Core zone, mainly comprising of metamorphic rocks, can be subdivided into two litho-units viz:(i) upper unit called as the High Himalaya Crystalline Sequence (HHCS) made of amphibolite facies migmatitic gneisses. The Main Central Thrust (MCT) separates the HHCS with other lithologies to the south, and (ii) the lower unit beneath the MCT is the Lesser Himalayan
Crystalline Sequence (LHCS), predominantly composed of amphibolite facies augen gneisses (para-ortho gneiss), and bounded at its base by the Munsiari Thrust.

In the NW Himalaya, these thrust sheets are exposed for a structural thickness up to $25 \mathrm{~km}$ along the deep cross-section cut by the Sutlej river across the High Himalayan range (Vannay et al. 2004; Caddick et al. 2007). Along the Sutlej section, the LHCS crops out within a tectonic window called the Larji-Kulu-Rampur Window (LKR Window) (Vannay et al. 2004)

Metamorphic evolution path, inferred from multiple equilibria thermobarometry, indicates peak temperatures increasing from $\sim 600$ to $750^{\circ} \mathrm{C}$ from the base to the top of the HHCS, with peak temperature conditions reaching at an almost constant pressure of $\sim$ kbar (Vannay and Grasemann,1998, 2001; Vannay et al. 1999; Vannay et al. 2004). Peak conditions in the underlying LHCS also reached at about $30 \mathrm{~km}$ depth ( 8 kbar) in the lower LHCS unit.

The metamorphic peak was directly followed by cooling during decompression, implying a lack of significant thermal relaxation during exhumation. This retrograde P-T evolution, thus, reflects a rapid cooling of the HHCS gneiss sheet, as a consequence of underthrusting beneath the MCT of colder rocks from shallower structural levels (Vannay and Grasemann, 2001).

Later a more refined P-T-t path of the LHC from the Sutlej section has been proposed by Caddick et al. (2004). It depicts the early burial and late exhumation history of the studied area. Data implies burial to ca. $7.5 \mathrm{kbar}$ with resultant heating through reactions producing staurolite and garnet at ca. $10 \mathrm{Ma}$. Biotite then grew at the expense of chlorite at ca. $580^{\circ} \mathrm{C}$, inferred using garnet zoning,modal proportion of biotite, loss of prograde chlorite and the absence of kyanite growth all implying a maximum temperature of $600-640{ }^{\circ} \mathrm{C}$ at intermediate pressure. It has also been suggested that the P-T path closure around the point of maximum temperature is consistent with heating due to overthrusting of the hot HHCS, followed by tectonically-driven exhumation (Harrison et al. 1998; Catlos et al. 2001; Kohn et al. 2001). Similar 'hairpin PT paths' have been deduced from the Lesser Himalaya of central Nepal (Catlos et al. 2001; Kohn et al. 2001), although lower maximum temperatures were attained there.

\section{Sikkim Himalaya (Fig.2)}

As is mentioned above that inverted Barrovian metamorphic sequence has been observed along the entire Himalayan length. One of the well-studied sections of the same is along the Sikkim Himalaya in the east (Neogi et al. 1998; Ganguly et al. 2000; Dasgupta et al. 2004). A detailed petrographic and metamorphic study of the metapelite sequence along the Rangoli transect in the Eastern Sikkim Himalaya have been studied by Dasgupta et al. (2004). Their work concluded a progressive increase of both temperature and pressure with increasing grade and structural height through the MCTZ and the lower part of the HHCS. Also there is no indication of polymetamorphic history in the zoning profiles of garnet. There P-T results contradict the fact that increase in $\mathrm{T}$ along the upper section of this Barrovian sequence of Himalaya is associated with decrease in pressure conditions.

Ganguly et al. (2000) have also worked on the metamorphic exhumation path of the pelitic rocks from the same area (HHCS rocks from the Sikkim-Darjeeling section). They calculated peak metamorphic conditions as $\sim 10.4 \mathrm{kbar}, 800^{\circ} \mathrm{C}$ temperature and extremely rapid $(\sim 15 \mathrm{~mm} / \mathrm{yr})$ exhumation up to the depth of $\sim 15 \mathrm{~km}$ 
followed by a much slower process $\sim 2 \mathrm{~mm} / \mathrm{yr}$, up to at $\sim 5 \mathrm{~km}$ depth, specifically on the basis of mineral equilibria and compositional zoning in garnets. Their work proposed that the change of the exhumation rate might reflect a process of tectonic thinning followed by erosion and/or horizontal flow at shallow depth and suggests that the HHCS samples studied along this section of the Himalaya exhumed from a depth of $\sim 34 \mathrm{~km}$ within $\sim 8 \mathrm{Ma}$.

\section{Arunachal Himalaya (Fig. 2)}

The Higher Himalayan Crystallines have been exposed in the Arunachal Himalaya also and have been studied by many workers (Yin et al. 2006, 2010; Warren et al. 2014 and Goswami et al. 2014). Lithologically, the HHC in Arunachal are mainly comprised of highgrade sillimanite-bearing migmatitic gneisses, equivalent to those described from similar structural levels along orogenic strike (e.g. Gansser 1983; Hodges 2000).

Metasediments along the Lumla Formation (LF) is a thrust-bound window through GHS (Yin et al. 2010) in the Arunachal Himalaya. To the north of LF, garnet grade schists and gneiss are in contact with garnet free-sillimanite gneisses along 'Zimithang Thrust'. This thrust is correlated with the Kakhtang thrust in Bhutan by many workers (Grujic et al. 1996; Yin et al. 2006, 2010). Metamorphic conditions along the Zimithang Thrust have been studied in detail by Warren et al.(2014). The peak temperature was calculated as $\sim 525-650^{\circ} \mathrm{C}$ in the hanging and footwalls and ${ }^{40} \mathrm{Ar} /{ }^{39} \mathrm{Ar}$ muscovite data from samples from either side of the thrust yield ages of $\sim 7 \mathrm{Ma}$. Monazite grains in biotite-sillimanite gneiss in the hanging wall yielded ages of $16 \pm$ 0.2 to $12.7 \pm 0.4 \mathrm{Ma}$, while those of the footwalls yielded an older monazite ages of $27.3 \pm 0.6$ to $17.1 \pm 0.2$ (Wallis et al. 2014; Warren et al. 2014).

Also, their analyses yield muscovite ${ }^{40} \mathrm{Ar} /{ }^{39} \mathrm{Ar}$ ages that are younger than those yielded by similar muscovite grain size fractions from granites and gneisses at similar structural levels along strike further to the west in Bhutan ( 11 Ma; Maluski et al. 1988), Sikkim ( 13 Ma; Kellett et al. 2013), and in the Everest region in Nepal ( 15 Ma; Carosi et al. 1998). This trend suggests either later or slower cooling from the central to the eastern Himalaya.

An integrated P-T path of the Lesser Himalayan Sequence (comprises of garnet-kyanite grade metapelites along the footwall of the MCT) from the Arunachal Himalaya has also been discussed by Goswami et al. (2014). Their studies reveal a near isobaric (at P 89 kbar) peak Barrovian metamorphism with increase in T-maximum from $\sim 560{ }^{\circ} \mathrm{C}$ in the metagranite through $\sim 590-600{ }^{\circ} \mathrm{C}$ in the lower and middle garnet-zone to $\sim 600-630{ }^{\circ} \mathrm{C}$ in the upper garnet- and kyanite-zone rocks. The metamorphic sequence of the LHS additionally records a pre-Barrovian near isobaric thermal gradient in the mid crust (at $\sim 6 \mathrm{kbar}$ ) from $\sim 515^{\circ} \mathrm{C}$ (in the middle garnet zone) to $\sim 560-580^{\circ} \mathrm{C}$ (in the upper garnet- and kyanite zone, adjoining the Main Central Thrust).

They proposed a clockwise $\mathrm{P}-\mathrm{T}$ path from the studied section of the Arunachal GHS with the following sequence of metamorphic stages: burial to lower crustal depths, prograde heating leading to kyanite-facies partial melting at $\mathrm{T} \sim 750-800{ }^{\circ} \mathrm{C}$ and steep, near isothermal decompression to mid-crustal depths and subsequent postdecompressional cooling. Near identical GHS metamorphic P-T paths were previously established from the adjoining Bhutan (Daniel et al. 2003) and Sikkim Himalaya (Ganguly et al. 2000; Harris et al. 2004; Neogi et al.1998; Sorcar et al. 2014).

\section{Discussion}

Representative metamorphic conditions, available geochronological data for each of the above described zone viz. TransHimalaya, Suture zone and the Himalayan zone, for several localities are compiled in Table 1. The data listed in Table 1 and the metamorphic evolution in terms of P-T-t paths is discussed below. The paths are schematically shown (geochronologic data omitted) for the purpose of clarity in the accompanying figures.

1. Though initiation of the Himalayan orogen has been proposed during Paleozoic (e.g. Gehrels et al. 2003), geochronologic data does not supports this. The earliest phase inferred from the metamorphic assemblages possibly represents welding of 'Island Arc' (Ladakh) with the Asian plate during Cretaceous time (Trans-Himalaya metamorphism, Table 1). The oldest time for this metamorphism is reported to be $\sim 108 \mathrm{Ma}$ from the Pangong Metamorphic Complex (Streule et al. 2009) and plutonism towards west in the Hunza valley in Pakistan (Palin et al. 2012) where the peak metamorphic conditions were reported at $\sim 82 \mathrm{Ma}$ (Table 1 ). However, the Cretaceous metamorphism is overprinted by the Tertiary metamorphism, generally upto kyanite zone. In the Hunza valley, second sillimanite grade rocks (sillimanite $+\mathrm{K}$ feldspar-bearing metapelites) are reported along with migmatites (Palin et al. 2012).

2. The P-T paths for the Ladakh (Pangong Metamorphic Complex or PMC, Pangong Transpressional Zone or PTZ and Nubra valley) are plotted in Figure $3 \mathrm{a}$.

An inferred metamorphic path for the Hunza valley is also

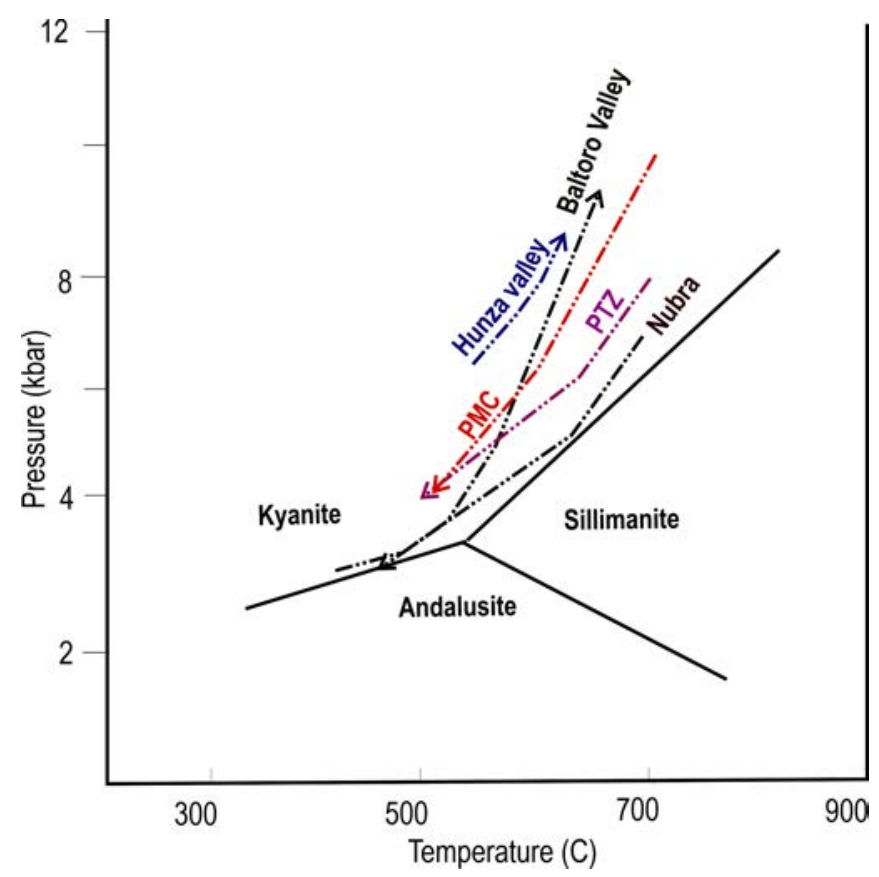

Figure 3a. The proposed P-T path for different metamorphic terrains from the Trans-Himalayan Zone. Blue and Black curve represents Hunza and Baltaroo valley region; Red, purple and dark brown colored curve represents Pangong Metamorphic Complex (PMC); Pangong Transpressional zone (PTZ) and Nubra valley terrains (for data references please refer Table 1 in text). Univariant reactions marked is from Pattison (1992; Ky-Sil-And). 
Table 1. Summary of metamorphic conditions including age and geological units of Trans-Himalaya, along Suture Zone and Himalaya along different geographical locations

\begin{tabular}{|c|c|c|c|c|c|}
\hline $\begin{array}{l}\text { METAMOR- } \\
\text { PHIC ZONE }\end{array}$ & $\begin{array}{l}\text { GEOLOGICAL } \\
\text { FORMATION }\end{array}$ & $\begin{array}{l}\text { METAMORPHIC } \\
\text { ROCK/UNITS }\end{array}$ & $\begin{array}{l}\text { AVERAGE } \\
P(\text { kbar })-T\left({ }^{\circ} C\right)\end{array}$ & $\begin{array}{l}\text { AVERAGE } \\
A G E(M a)\end{array}$ & REFERENCES \\
\hline \multirow{11}{*}{$\begin{array}{l}\text { Trans-Himalayan } \\
\text { Metamorphic Zone } \\
\text { (THMZ) }\end{array}$} & \multicolumn{5}{|l|}{ (Western section } \\
\hline & \multicolumn{5}{|l|}{ of $\mathbf{T H})$} \\
\hline & \multirow[t]{2}{*}{ Baltoro Valley } & Amphibolite facies & Peak: 650-700C; & $\sim 28-22$ & \multirow{3}{*}{$\begin{array}{l}\text { Fraser et al. 2001; Foster et al. } \\
\text { 2004; Searle et al. 2010; } \\
\text { Palin et al. } 2012 \text { (and } \\
\text { references within) }\end{array}$} \\
\hline & & $\begin{array}{l}\text { Barrovian metamorphic } \\
\text { zone/Sillimanite- } \\
\text { chlorite grade rocks }\end{array}$ & $\begin{array}{l}6-10 \mathrm{~kb} \text { and } \\
\text { post peak: } \\
\sim 600 \mathrm{C} ; 4-7.5 \mathrm{~kb}\end{array}$ & $\sim 50-13$ & \\
\hline & Hunza valley & $\begin{array}{l}\text { K-fsp-sillimanite } \\
\text { bearing } \\
\text { metapelites/migmatite } \\
\text { followed by staurolite- } \\
\text { kyanite grade rocks }\end{array}$ & $\begin{array}{l}\text { Peak: } \sim 645 \mathrm{C} \\
7-8 \mathrm{~kb} \text { and post } \\
\text { peak: } \sim 550 \mathrm{C}\end{array}$ & $\sim 82-44$ & \\
\hline & \multicolumn{5}{|l|}{$\begin{array}{l}\text { (Eastern section } \\
\text { of } \mathbf{T H})\end{array}$} \\
\hline & $\begin{array}{l}\text { Pangong Transpres- } \\
\text { sional Zone (PTZ) }\end{array}$ & $\begin{array}{l}\text { Garnet-staurolite- } \\
\text { kyanite metapelites }\end{array}$ & $\begin{array}{l}\sim 400-700 \mathrm{C} \\
\sim 3-8.5 \mathrm{~kb}\end{array}$ & 10-17 & \multirow[t]{5}{*}{$\begin{array}{l}\text { Streule et al. 2009; Thanh et } \\
\text { al. 2011; Wallis et al. } 2014 \\
\text { (and references within) }\end{array}$} \\
\hline & Pangong & Sillimanite-staurolite & $\sim 600 \mathrm{C}$ & $\sim 108$ & \\
\hline & Metamorphic & grade metapelites & $\sim 6-7 \mathrm{~kb}$ & & \\
\hline & Complex (PMC) & & & & \\
\hline & $\begin{array}{l}\text { Nubra and Saesar } \\
\text { formations }\end{array}$ & $\begin{array}{l}\text { Metavolcanics of } \\
\text { greenschist facies }\end{array}$ & $\sim 600 \mathrm{C} ; 6.5 \mathrm{~kb}$ & $\sim 15$ & \\
\hline \multirow{9}{*}{$\begin{array}{l}\text { Himalayan } \\
\text { Metamorphic Zone } \\
(\text { HMZ) }\end{array}$} & \multicolumn{5}{|l|}{ Syntaxial Zone } \\
\hline & $\begin{array}{l}\text { Nanga Parbat } \\
\text { Haramosh massif }\end{array}$ & $\begin{array}{l}\text { Kyanite-K feldspar } \\
\text { gneisses }\end{array}$ & $\sim 700 \mathrm{C} ; 5 \mathrm{kbar}$ & $\sim 11-24$ & $\begin{array}{l}\text { Zeitler et al. 1993; } \\
\text { Whittington et al. 1996; }\end{array}$ \\
\hline & $\begin{array}{l}\text { Namche Barwa } \\
\text { Massif }\end{array}$ & $\begin{array}{l}\text { Granulite and } \\
\text { Cordietrite-spinel } \\
\text { bearing assemblage }\end{array}$ & $\sim 800 \mathrm{C} ; 10 \mathrm{~kb}$ & & $\begin{array}{l}\text { Booth et al. 2009; Guilmette } \\
\text { et al. 2011; Su et al. } 2012\end{array}$ \\
\hline & \multicolumn{5}{|l|}{ Western Himalaya } \\
\hline & $\begin{array}{l}\text { Sutlej section (along } \\
\text { LKR window) }\end{array}$ & $\begin{array}{l}\mathrm{HHC}+\mathrm{LHC} \\
\text { amphibolite facies } \\
\text { gneiss }\end{array}$ & $\sim 600-700 \mathrm{C} ; 8 \mathrm{~kb}$ & $\sim 10-18$ & $\begin{array}{l}\text { Verma, 1989; Vannay et al. } \\
\text { 2004;Caddick et al. 2007(and } \\
\text { references within) }\end{array}$ \\
\hline & \multicolumn{5}{|l|}{ Central Himalaya } \\
\hline & $\begin{array}{l}\text { Sikkim-Darjelling } \\
\text { section(along Rangoli } \\
\text { transect) }\end{array}$ & $\begin{array}{l}\text { HHC (metapelites) } \\
\text { Peak Metapelites } \\
\text { Lower Grade }\end{array}$ & $\begin{array}{l}\sim 800 \mathrm{C} ; 10 \mathrm{~kb} \\
\sim 500-600 \mathrm{C} ; 5-7 \mathrm{~kb}\end{array}$ & & $\begin{array}{l}\text { Ganguly et al. 2000; Dasgupta } \\
\text { et al. } 2004\end{array}$ \\
\hline & \multicolumn{5}{|l|}{ Eastern Himalaya } \\
\hline & $\begin{array}{l}\text { Arunachal section } \\
\text { (Lumla Formation } \\
\text { along Zimithang thrust) }\end{array}$ & $\begin{array}{l}\text { HHC (high-grade } \\
\text { sillimanite gneiss) } \\
\text { LHC (garnet-kyanite } \\
\text { grade rocks) }\end{array}$ & $\begin{array}{l}\sim 500-650 \mathrm{C}, 7-10 \mathrm{~kb} \\
\sim 500-750 \mathrm{C}, 6-9 \mathrm{kbar}\end{array}$ & $7-17$ & $\begin{array}{l}\text { Goswami et al. 2014; } \\
\text { Wallis et al. 2014; Warren et } \\
\text { al. } 2014 \text { (and references } \\
\text { within) }\end{array}$ \\
\hline
\end{tabular}

shown in this figure. These represent the Tertiary metamorphic event but on account of limited geochronological constraints, the paths may be considered schematic. Differences in the geological conditions (e.g. absence of the Hunza Plutonic Complex magmatic equivalents in Ladakh) are reflected in the nature of metamorphic evolution of the western and eastern domains of this sector in clockwise paths for the Ladakh metamorphic units and counter-clockwise path for the Hunza valley. It is possible that the heat sources for the Ladakh area was geothermal gradient-controlled, while the dissipation of the heat from the Hunza Plutonic Complex contributed significantly to the metamorphic transformations in the western locality. There is lack of any reported data for the
Cretaceous age metamorphism from the central and eastern sectors. The moderately steep nature of P-T path and lack of significant overstepping from amphibolite facies conditions (Fig. 3a) indicates that the Trans-Himalayan terrain was exhumed at a fast rate during Tertiary and the metamorphic conditions were generally moderate.

3. The Indus Tsangpo Suture Zone Metamorphism (ITSZM) is summarised in Table 1 and Fig. $3 \mathrm{~b}$ from three areas from west to east, namely, the Kaghan valley (Pakistan), Tso Morari (Himachal Himalaya, India) and Ama Drime (Nepal). All the three domains depict presence of medium temperature eclogites with coesite reported from the Kaghan valley and the Tso Morari and relatively lower pressure UHP assemblages 
from the Ama Drime locality. The central locality of Tso Morari indicates presence of oldest UHP rocks at $\sim 57 \mathrm{Ma}$ (Table 1 ) with the western and the eastern occurrences $\sim 10 \mathrm{Ma}$ younger and limits the earliest age of subduction of the Indian plate. Recent data suggests this to have occurred at $\sim 49 \mathrm{Ma}$ (Shellnutt et al. 2014; Laskowski et al. 2016). The exhumation process is suggested to be spasmodic with a considerable, though indeterminate, residence time at various stages. However, the final exhumation appears to pre-date the peak of the Himalayan metamorphism.

The paths are typically clockwise with the steepest exhumation rates for the Tso Morari UHP rocks (Fig. 3b). Though there is considerable uncertainty on the prograde component of the P-T paths of the UHP rocks, an amphibole composition derived path (Singh et al. 2013) indicates slab-break off and tectonic decompression as the primary mechanisms for the burial and exhumation. An along-strike non-uniform behaviour of the leading subducting edge is also suggested by the metamorphic data.

4) The Himalayan metamorphism represents one of the most prominent manifestations of the Himalayan orogeny along the entire strike length of the mountain belt and therefore is most well studied (Table 1 and Fig. 3c). For most part it is represented by a clockwise metamorphic path typical of the underthrust block of continental crust thickened by two converging continental blocks (Nanga Parbat, Sutlej, Bhutan, Sikkim and Namche Barwa P-T-t paths in Fig. 3c).

Sections representing deeper (and higher peak T) lithology shows a distinct decompression path (presence of cordieritebearing assemblages especially close to the syntaxial bands) while relatively shallower metamorphic sequences lack this feature. Combining the two it is apparent that the peak temperature of the Himalayan metamorphism should represent significant overstepping $\left(50-100^{\circ} \mathrm{C}\right)$ beyond the second sillimanite isograd (of metapelites) into the granulite facies. It is of interest to note here that the apparently laterally continuous units (e.g. LHS, GHS) is not reflected in their metamorphic behaviour (e.g. Diachroneity of peak metamorphism of the GHS, Wang et al. 2015). These authors suggested a $10 \mathrm{Ma}$ age gap between the differential exhumation of the Greater Himalayan Crystallines. The upper block being exhumed along South Tibet Detachment (STD) at 27-25 Ma and the lower block of this unit being exhumed along MCT at $\sim 16 \mathrm{Ma}$. Thus, the episodic nature of the Himalayan metamorphism is indicated. In the LHS of Nepal, Paudel and Arita (2000) describe two metamorphic events, M1 and M2 with the latter being of higher grade. They consider M1 to be possibly early Tertiary. The earlier proposed generalized P-T-t path (e.g. Verma, 1989), therefore, is typical of only central western Himalaya. It is also evident that the exhumation rates along the Himalayan strike lengths are unequal with these being much higher at the two syntaxes (e.g. Zhang et al. 2015; King et al.2016; Lang et al.2016; Butler, 2018). When we examine the available geochronological dataset (e.g. Table 1) it is evident that the evolving nature of the Himalayan metamorphism is well reflected in variable but younger dates from $\sim 24 \mathrm{Ma}$ onwards. An excellent correlation of the granite generation with the Tertiary metamorphism was presented by Verma (2003) but

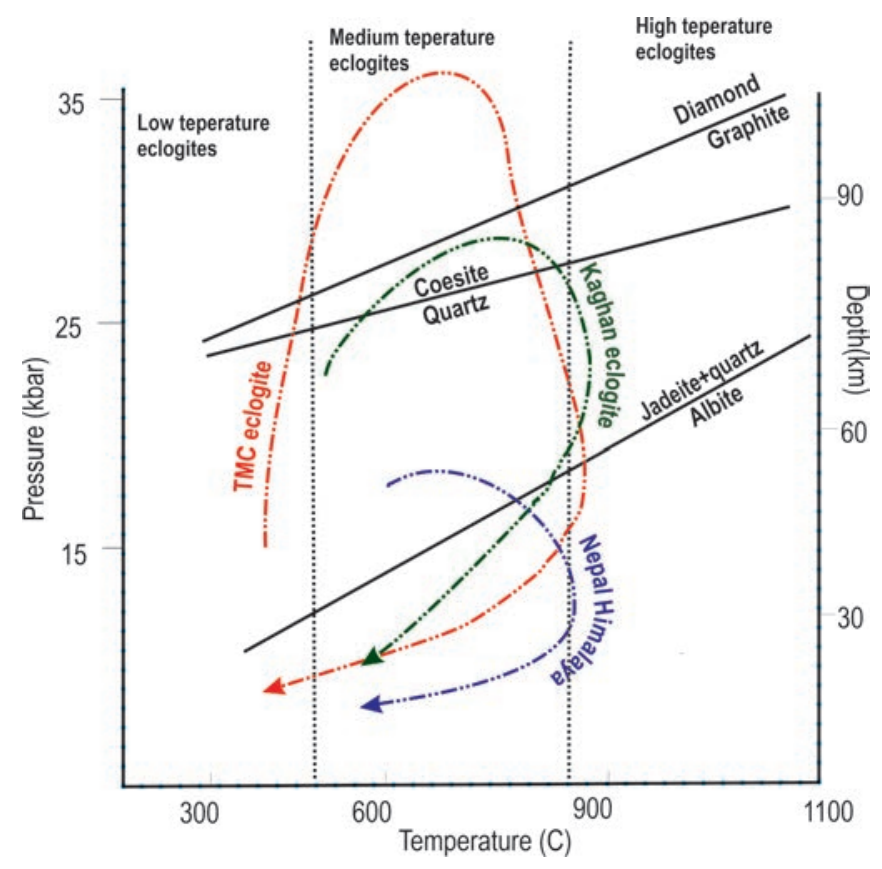

Figure $3 b$. The proposed $P-T$ path for different HP/UHP eclogites from the Himalaya near suture zone. Red curve represents TMC; green is for Kaghan Valley and blue curve is for Ama Drime, Nepal eclogites (for references please refer Table 1 in text). Univariant reactions marked are from Bohlen and Butcher (1982; Qtz-Coe), Holland (1980; Ab-Jd-Qtz), and Day (2012; Dia-Gph).

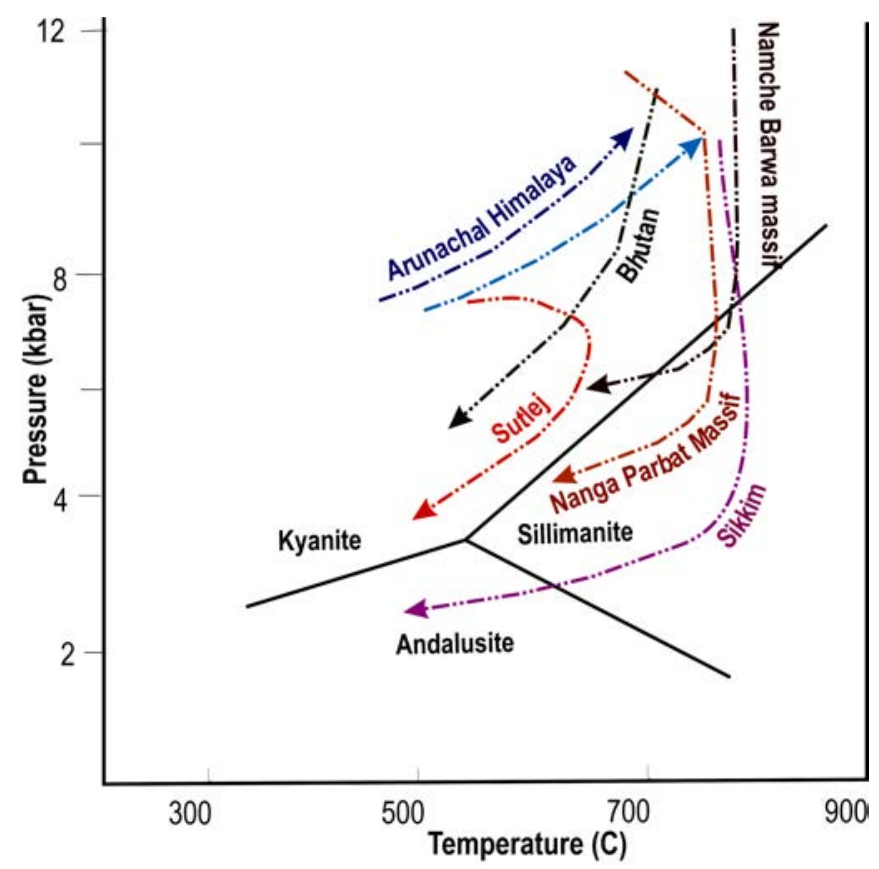

Figure 3c. The proposed P-T path for different metamorphic terrains from the Himalaya. Blue (light and dark) represents LHS and GHS from Arunachal Himalayan metamorphic sections; black colored path represents Bhutan Himalaya; brown colored paths (light and dark brown) are for two Syntaxial zones; red colored path represents Sutlej section and purple colored path represents Sikkim Himalayan metamorphic section (for references please refer Table 1); Univariant reactions marked are from Pattison (1992; Ky-Sil-And). 
the melt products have not been considered in the present summary.

A comprehensive look at the three components allows us to conclude that the Himalayan metamorphic event can be considered to have begun in Cretaceous with the major outcome being the suturing of 'island arc' lithologies with the Asian plate. The Hunza valley succession and telescoping of southward younging tectonic and metamorphic domains shows that, though episodic, it was a continuing geodynamic process and cannot be segregated from the Himalayan metamorphism. Though there are differences between the subsequent metamorphic evolution of overthrust and underthrust blocks as discussed above, presence of Tertiary and younger granite in both Himalayan and the Trans-Himalayan blocks (e.g. Searle et al.2001, 2010) coupled with relatively lower grade of metamorphism in THM indicates melt sourcing from that generated in the lower (Indian) block through crustal scale faults such as the Karakoram fault. Several studies characterizing metamorphic rocks combined with new geochronologic data also supports episodic nature of metamorphism with atleast two metamorphic events during the latest Tertiary time. Incorporating these details is essential to arrive at a refined geodynamic model of the Himalayan orogeny.

\section{Acknowledgments}

NCP and PS acknowledge support of MoES funded project ['Age Constraints on metamorphic evolution of the Trans-Himalayas': 'MoES/P.O. (Geol/101(b)/2017)']. Jeev Jatan Sharma assisted in the preparation of figures. AKJ acknowledges financial support under the INSA Honorary Scientist Program at the CSIR-Central Building research Institute, Roorkee.

\section{References}

Ahmad, T., Islam, R., Khanna, P.P. and Thakur, V. C.,1996, Geochemistry, petrogenesis and tectonic significance of the basic volcanic units of the Zildat Ophiolitic mélange, ISZ, E Ladakh. Geodinamica Acta, v. 9, p1-12.

Avouac, J.P. and Tapponier, P., 1993, Kinematic model of active deformation in central Asia. Geophysical Research Letters, v.20, p895-898.

Baig, M.S., Lawrence, R.D., Snee, L.W., 1988, Evidence for late precambrian to Early Cambrian Orogeny in northwest Himalaya, Pakistan. Geological Magazine, v. 125, p83-86.

Berthelsen, A.,1953, On the geology of the Rupshu District, N Himalaya Medd Dan. Geology Forening, v. 12, p350-415.

Bohlen, S. R. and Boettcher, A. L., 1982, The quartz-coesite transformation: A precise determination and effects of other components. Journal of Geophysical Research, v.87, p7073-7078.

Booth, A.L., Chamberlain, C.P., Kidd, W.S.F., Zeitler, P.K., 2009, Constraints on the metamorphic evolution of the eastern Himalayan syntaxis from geochronologic and petrologic studies of Namche Barwa. Geolological Society of American Bulletin, v.121, p385-407.

Butler, R.W.H., 2018, Tectonic evolution of the Himalayan syntaxes: the view from Nanga Parbat. Geological Society, London, Special Publications, v. 483, DOI: 10.1144/SP483.5

Caddick, M. J., Bickle, M. J., Holland, T. J. B., Harris, N. B. W., Horstwood, M. S. A., Parrisch, R. R. and Ahmad, T., 2004, Burial and exhumation history of a Lesser Himalayan schist: Recording the formation of an inverted metamorphic sequence in NW India. Earth and Planetary Science Letters, v. 264, p375-390.
Carosi, R., Lombardo, B., Molli, G., Musumeci, G. and Pertusati, P.C., 1998, The south Tibetan detachment system in the Rongbuk valley, Everest region. Deformation features and geological implications. Journal of Asian Earth Sciences, v. 16, p299-311. http://dx. doi.org/10.1016/S0743-9547(98)00014-2.

Catlos, E.J., Harrison, T.M., Kohn, M.J., Grove, M., Ryerson, F.J., Manning, C.E. and Upreti, B.N., 2001, Geochronologic and thermobarometric constraints on the evolution of the Main Central Thrust, Central Nepal Himalaya. Journal of Geophysical Research, v. 106, p16177-16204.

Chawla, H.S., Marquer, D., Kramers, J.D., Villa, M.I. and Bussy, F., 2000, Petrology and age of the Kinnaur Kailash granite: evidences for an Ordovician post-orogenic extension in the High Himalayan Crystalline, Sutlej, India. Earth Science Frontiers 7., China University of Geosciences Beijing, pp.50-54.

Cottle, J.M., Jessup, Micah J., Newell, Dennis L. Matthew, S., Horstwood, A., Noble, Stephen R., Parrish, Randall R., Waters, David J. and Searle, Michael P.,2009, Geochronology of granulitizedeclogite from the Ama Drime Massif: Implications for the tectonic evolution of the South Tibetan Himalaya. Tectonics, v. 28, p1-25: TC1002, doi:10.1029/2008TC002256.

Daniel, C.G., Hollister, L.S., Parrish, R.R., Grujic, D., 2003, Exhumation of the Main Central Thrust from lower crustal depths, eastern Bhutan Himalaya. Journal of Metamorphic Geology, v. 21, p317-334.

Dasgupta, S., Ganguly, J. and Neogi, S., 2004, Inverted metamorphic sequence in the Sikkim Himalaya: crystallization history, P-T gradient and implications. Journal of Metamorphic Geology, v. 22, p395-412.

Day, H.W., 2012, A revised diamond-graphite transition curve. American Mineralogist, v.97, p52-62.

Dewey, J. F. and Burke, K. C. A., 1973, Tibetan, Variscan and Precambrian basement reactivation: products of a continental collision. Journal of Geology, v.81, p683-692.

Epard. J.L. and Steck, A.,2008, Structural development of the Tso Morari ultra-high pressure nappe of the Ladakh Himalaya. Tectonophysics, v.451, p242-264.

Foster, G. and Parrish, R., 2003, Metamorphic monazite and the generation of P-T-t paths. Geological Society, London, Special Publications, v. 220, p25-47.

Fraser, J.E., Searle, M.P., Parrish, R.R. \& Noble, S.R., 2001, Chronology of deformation, metamorphism, and magmatism in the southern Karakoram Mountains. Geological Society of America Bulletin, v.113, p1443-1455.

Ganguly, J., Dasgupta, S., Cheng, W. and Neogi, S., 2000, Exhumation history of a section of the Sikkim Himalaya, India: records in the metamorphic mineral equilibria and compositional zoning of garnet. Earth and Planetary Science Letters, v. 183, p471-486.

Gansser, A., 1964, Geology of the Himalaya, John Wiley, London, 289 p.

Gansser, A., 1974, Himalaya. Mesozoic Cenozoic Orogenic Belts: Data for Orogenic Studies. Geological Society of London, Special Publication, London, v.4, p267-278.

Gansser, A., 1983, Geology of the Bhutan Himalaya. Birkaeuser Verlag, Basel.

Garzanti, E., Critelli, S., Ingersoll, R.V., 1996, Paleogeographic and paleotectonic evolution of the Himalayan range as reflected by detrital modes of Tertiary sandstones and modern sands. Geological Society of American Bulletin, v. 108, p631-642.

Gehrels, G.E., DeCelles, P.G., Martin, A., Ojha, T.P., Pinhassi, G. and Upreti, B.N., 2003, Initiation of the Himalayan Orogen as an Early Paleozoic Thin-skinned Thrust Belt. GSA Today, pp.1-9.

Goswami, B., S., Bhowmik, S.K., Dasgupta, S., Pant, N.C., 2014, Burial of thermally perturbed Lesser Himalayan mid-crust: 
Evidence from petrochemistry and P-T estimation of the western Arunachal Himalaya, India. Lithos, v.208-209, p298-311.

Groppo, C., Lombardo, B., Rolfo, F. and Pertusati, P., 2007, Clockwise exhumation path of granulitized eclogites from the AmaDrime range (Eastern Himalaya). Journal of Metamorphic Geology, v.25, p51-75.

Grujic, D., Casey, M., Davidson, C., Hollister, L.S., Kündig, R., Pavlis, T., Schmid, S., 1996, Ductile extrusion of the Higher Himalayan Crystalline in Bhutan. evidence from quartz microfabrics: Tectonophysics, v. 260, p21-43.

Guilmette, C., Hébert, R., Wang, C. and Villeneuve, M., 2009, Geochemistry and geochronology of the metamorphic sole underlying the Xigaze Ophiolite, Yarlung Zangbo Suture Zone, South Tibet. Lithos, v.112, p149-162.

Guilmette, C., Hébert, R., Dostal, J., Indares, A., Ullrich, T., Bédard, E. and Wang,C., 2012, Discovery of a dismembered metamorphic sole in the Saga ophiolitic mélange, South Tibet: assessing an Early Cretaceous disruption of the Neo-Tethyan supra-subduction zone and consequences on basin closing. Gondwana Research, v.22(2), p398-414

Guilmette C, Indares A, H’ebert R., 2011, High-pressure anatectic paragneisses from the Namche Barwa, Eastern Himalayan Syntaxis: textural evidence for partial melting, phase equilibria modeling and tectonic implications. Lithos,v.124, p66-81.

Harris, N.B.W., Caddick, M., Kosler, J., Goswami, S., Vance, D., Tindle, A.G., 2004, The pressure-temperature-time path of migmatites from the Sikkim Himalaya. Journal of Metamorphic Geology, v.22, p249-264.

Harrison, T. M., Grove, M., Lovera, M. and Catlos, E.J., 1998, A model for the origin of Himalayan anatexis and inverted metamorphism. Journal of Geophysical Research, v.103, p27017 $-27032$.

Hodges, K.V., 2000, Tectonics of the Himalaya and southern Tibet from two perspectives. Geological Society of American Bulletin, v.112, p324-350.

Hodges, K.V., 2003, Geochronology and Thermochronology in orogenic system. The Crust, eds., R.L. Rudnick, 263-39 in Treatise on Geochemistry, v. 3; Elsevier, New York.

Holland, T.J.B., 1980, The reaction albite $=$ jadeite + quartz determined experimentally in the range $600-1200^{\circ} \mathrm{C}$. American Mineralogist, v.65, p129-34.

Honegger, K., Dietrich, J., Frank, W., Gansser, A, Thoni, M. and Trommsdorff, W.,1982, Magmatism and Metamorphism. The Indus Tsangpo Suture Zone: Earth and Planetary Science Letters. v.60, p253-292.

Honegger, K., LeFort, P., Mascle G. and Zimmermann, J.L., 1989, The blueschists along the Indus Suture Zone in Ladakh, NW Himalaya. Journal Of Metamorphic Petrology, v.7, p57-72.

Jain, A.K. and Singh, S., 2008, Tectonics of the southern Asian plate margin along the Karakoram Shear Zone. Constraints from field observations and U-Pb Shrimp ages: Tectonophysics, v., 451, p186-205.

Jain, A.K., Dasgupta, S., Bhargwa, O.N., Patel, R. and Mukul, M., Md. Israil, Perumal, J.R., Patel, R.C., Mukul, M., Parcha, S.K., Adlakha V., Agarwal K.K., Sing P., Bhattacharya, K., Pant N.C. and Banerjee, D.M., 2016, Tectonics and Evolution Of the Himalaya. Precambrian Indian National Science Academy, v.82(3), July Special Issue, p581-604: DOI: 10.16943/ptinsa/ 2016/48469

Joshi, M, Singh, B.N. and Goel, O.P., 1994, Metamorphic conditions of the aureole rocks from Dhunaghat area, Kumaun Lesser Himalaya. Current Science, v. 67, p185-188.

Kaneko, Y., Katayama, I., Yamamoto, H., Misawa, K., Ishikawa, M., Rehman, H.U., Kausar, A.B., Shiraishi, K., 2003, Timing of
Himalayan ultrahigh-pressure metamorphism: sinking rate and subduction angle of the Indian continental crust beneath Asia. Journal of Metamorphic Geology, v. 21( 6), p589-599.

Kellett, D.A., Grujic, D., Cout and, I., Cottle, J. and Mukul, M., 2013, The South Tibetan detachment system facilitates ultra rapid cooling of granulite-facies rocks in Sikkim Himalaya. Tectonics, v. 32, p252-270. http://dx.doi.org/10.1002/tect.2014.

King, G.E., Herman, F., Guralnik, B., 2016, Northward migration of the eastern Himalayan syntaxis revealed by OSL thermochronometry. Science, v.353 (6301), p800-4 DOI: 10.1126/ science.aaf 2637.

Klootwijk, C.T., Gee J.S., Peirce, J.W., Smith, G.M. and McFadden, P.L., 1992, An early India-Asia contact: paleomagnetic constraints from Ninety East Ridge, ODP Leg 121.Geology,v. 20, p395-398.

Kohn, M.J., Catlos, E.J., Ryerson, F.J. and Harrison, T.M., 2001, Pressure-temperature-time path discontinuity in the Main Central Thrust Zone, Central Nepal. Geology, v. 29, p571-574.

Kohn, M.J., 2014, Himalayan Metamorphism and Its Tectonic Implications. Annual Review of Earth and Planetary Sciences, v.42, p381-419.

Kundu, A., Sundarraman, S., Pant, N.C. and Joshi, S., 2008, Mineral chemistry of major and accessory phases of Mandi granite: Response of a Pan-African granite of Lesser Himalaya to the influence of Himalayan Metamorphism. GSI Special Publication, No. 91, pp. 79-104.

Lang, K.A., Huntington, K.W., Burmester, R., Housen, B., 2016, Rapid exhumation of the eastern Himalayan syntaxis since the late Miocene. Geological Society of American Bulletin, v.128 (9-10), p1403-1422.

Larson, K., Burgmann, R., Bilham, R. and Freymueller, J.T., 1999, Kinematics of the IndiaEurasia collision zone from GPS measurements. Journal of Geophysical Research, v. 104, p107793.

Le Fort, P., 1975, Himalaya: the collided ranges. Present knowledge of the continental arc. American Journal of Science, v. 275A, p144.

Le Fort, P., 1996, Evolution of the Himalaya, in Yin, A., Harrisan, T.M., eds., The Tectonics of Asia, Cambridge Univ. Press, New York, 95-106.

Leech, M.L., Singh, S., Jain, A.K., Klemperer, S. L. and Manickavasagam, R.M., 2005, The onset of India-Asia continental collision: early, steep subduction required by the timing of UHP metamorphism in W Himalaya. Earth and Planetary Science Letters, v. 234, p83-97.

Liou, J.G., Tsujimori, T., Zhang, R.Y., Katayama, I. and Maruyama, S., 2004, Global UHP metamorphism and continental subduction/ collision- The Himalayan Model. International Geological Reviews, v.46, p1-27.

Mahe'O, G., Guillot, S., Blichert-Toft, J., Rolland, Y. \& Pecher, A., 2002, A slab breakoff model for the Neogene thermal evolution of South Karakoram and South Tibet. Earth and Planetary Science Letters, v.195, p45-58.

Maluski, H., Matte, P., Brunel, M., Xiao, X., 1988, 40Ar/39Ar dating ofmetamorphic and plutonic events in the North and High Himalaya Belts (Southern Tibet, China).Tectonics, v.7, p299-326.

Marquer, D., Chawla, H. S. and Challandes, N., 2000, Pre-alpine high-grade metamorphism in High Himalaya crystalline sequences: Evidence from Lower Palaeozoic Kinnaur Kailas granite and surrounding rocks in the Sutlej Valley (Himachal Pradesch, India), Eclogae Geologicae Helvetiae, v. 93, p207-220.

Miller, C., Thöni, M., Frank, W., Grasemann, B., Klötzli, U., Guntli, P., Draganits, E., 2001, The early Palaeozoic magmatic event in the Northwest Himalaya, India: source, tectonic setting and age of emplacement. Geological Magazine, v. 138, p237- 251. 
Neogi, S., Dasgupta, S. and Fukuoka, M., 1998, High P-T polymetamorphism, dehydration melting and generation of migmatites and granites in the Higher Himalayan Crystalline Complex, Sikkim, India. Journal of Petrology, v. 39, p61-99.

Oliver, G., Johnson, M.R.W. and Fallick, A.E., 1995, Age of metamorphism in the Lesser Himalaya and the Main Central Thrust zone, Garhwal India: results of illite crystallinity, 40Ar39Ar fusion and K-Ar studies. Geological Magazine, v.132(02), p139 - 149.

O'Brien, P.J., 2018, Eclogites and other high-pressure rocks in the Himalaya: a review. From: Treloar, P. J.\& Searle, M. P. (eds) Himalayan Tectonics: A Modern Synthesis. Geological Society, London, Special Publications, v. 483.

Palin, R.M., Searle, M.P., Waters, D.J., Horstwood, M.S.A. and Parrish, R.R., 2012, Combined thermobarometry and geochronology of peraluminous metapelites from the Karakoram metamorphic complex, North Pakistan; New insight into the tectonothermal evolution of the Baltoro and Hunza Valley regions. Journal of Metamorphic Geology, v. 30, p793-820.

Pant, N.C., Kundu, A., Kumar, R., Dorka, B.S., Prasher, S., 2006, Paleoproterozoic metamorphism in the Jeori-Wangtu Gneissic Crystallines (JWGC), Western Himalaya. Journal of Asian Earth Science, v. 26, p585-604.

Pattison, D.R.M., 1992, Stability of andalusite and sillimanite and the $\mathrm{Al}_{2} \mathrm{SiO}_{5}$ triple point; constraints from the Ballachulish aureole, Scotland. Journal of Geology, v.100, p423-46.

Paudel, L.P. and Arita, K., 2000, Tectonic and polymetamorphic history of Lesser Himalaya in central Nepal. Journal of Asian Earth Science, v. 18, p561-584.

Pognante, U. and Spencer, D.A., 1991, First report of eclogites from the Himalayan belt, Kaghan valley (Pakistan): European Journal of Mineralogy, v.3, p613-618.

Rehman, H.U., Yamamoto, H., Khalil, M.A.K., Nakamura, E., Zafar, M., Khan, T., 2008, Metamorphic history and tectonic evolution of the Himalayan UHP eclogites in Kaghan Valley, Pakistan. Journal of Mineralogical and Petrological Sciences,v. 13, p242254.

Rolland, Y., Pêcher, A., 2001, The Pangong granulites of the Karakoram Fault (Western Tibet): vertical extrusion within a lithosphere-scale fault? Earth and Planetary Science Letters, v. 332, p363-370.

Rolland, Y., Maheo, G., Pecher, I. and Villa, M., 2009, Syn-kinematic emplacement of the Pangong metamorphic and magmatic complex along the Karakorum Fault (N Ladakh). Journal of Asian Earth Sciences, v., 34(1), p10-25.

Schärer, U. and Allegre, C.J., 1983, The Palung granite (Himalaya): High resolution $\mathrm{U}-\mathrm{Pb}$ systematics in zircon and monazite. Earth and Planetary Science Letters, v.63, p423-432.

Searle, M.P., 1996, Cooling history, erosion, exhumation, and kinematics of the Himalaya-Karakoram-Tibet orogenic belt. In the Tectonic evolution of Asia, Eds. A Yin, T. M. Harrison, 110137. New York. Cambridge, University Press.

Searle, M.P., Owen, L.A., 1999, The evolution of the Indus River in relation to topographic uplift, climate and geology of western Tibet, the Trans-Himalayan and High-Himalayan Range. In: The Indus River: Biodiversity, Resources, Humankind. Oxford University Press, Delhi, pp. 210-230.

Searle, M.P., Simpson, R.L., Law, R.D., Parrish, R.R. and Waters, D.J., 2003, The structural geometry, metamorphic and magmatic evolution of the Everest massif, High Himalaya of Nepal - South Tibet. Journal of the Geological Society, London, v.160, p345366.

Searle, M.P., Phillips, R.J., 2007, Relationships between right-lateral shear along the Karakoram Fault and metamorphism, magmatism, exhumation and uplift: evidence from the K2-GasherbrumPangong Ranges, north Pakistan and Ladakh. Journal of the Geological Society, London, v. 164, p439-450.

Searle, M.P., Parrish, R.R., Thow, A.V., Noble, S., Phillips, R.J. \& Waters, D.J., 2010, Anatomy, age and evolution of a collisional mountain belt: the Baltoro granite batholith and Karakoram Metamorphic Complex, Pakistani Karakoram. Journal of the Geological Society, v.167, p183-202.

Searle, M. P., Elliott, J. R., Phillips, R. J., \& Chung, S. L., 2011, Crustal-lithospheric structure and continental extrusion of Tibet. Journal of the Geological Society, v.168, p633- 672.

Searle, M. P., 2015, Mountain Building, Tectonic Evolution, Rheology, and Crustal Flow in the Himalaya, Karakoram, and Tibet. In: Gerald Schubert (editor-in-chief) Treatise on Geophysics, 2nd edition, 6, Oxford, Elsevier, 469-511.

Laskowski, A. K., Kapp, P., Vervoort Jeff, D. and Ding L., 2016, High-pressure Tethyan Himalaya rocks along the India-Asia suture zone in southern Tibet. The Geological Society of America, v.8(5), p574-582.

Shellnutt, J.G., Lee Tung-Yi, Brookfield, M.E. and Chung, Sun L., 2014, Correlation between magmatism of the Ladakh Batholith and plate convergence rates during the India-Eurasia collision. Gondwana Research, v.26, p1051-1059,http://dx.doi.org/10.1016/ j.gr.2013.09.006.

Singh, P., Saikia, A., Pant, N.C. and and Verma, P.K., 2013, Insights into the P-T evolution path of Tso Morari eclogites of the northwestern Himalaya: Constraints on the geodynamic evolution of the region. Journal of Earth System Science, v. 122(3), p677698.

Srikantia, S. V. and Bhargava, O. N., 1978, The Indus tectonic belts of Ladakh Himalaya: Its geology, significance and evolution. In Tectonic Geology of the Himalaya Ed: P.S, Saklani. Today and Tomorrow's Printers and Publishers, pp.43-62.

Srikantia, S.V. and Bhargava, O. N., 1983, Geology of the Palaeozoic sequence of the Kashmir Tethys Himalayan Basin in the Lidder Valley, Jammu and Kashmir. Journal, Geological Society of India, 24, pp.363-377.

Sorcar, N., Hoppe, U., Dasgupta, S. and Chakraborty, S., 2014, Hightemperature cooling histories of migmatites from the High Himalayan Crystallines in Sikkim, India: rapid cooling unrelated to exhumation. Contributions to Mineralogy and Petrology, v.167(2), p957 http://dx.doi.org/10.1007/s00410-013-0957-3.

Streule, M.J., Phillips, R.J., Searle, M.P.,Waters, D.J., Horstwood, M.S.A., 2009, Evolution and chronology of the Pangong Metamorphic Complex adjacent to the Karakoram Fault, Ladakh: constraints from thermobarometry metamorphic modelling and $\mathrm{U}-\mathrm{Pb}$ geochronology. Journal of Geological Society of London, v.166, p919-932.

Stöcklin, J., 1980, Geology of Nepal and its regional frame. Journal Geological Society London, v.137, p1-34

Su W, Zhang M, Liu XH, Lin JF, Ye K, Liu X., 2012, Exact timing of granulite metamorphism in the Namche Barwa, eastern Himalayan syntaxis: new constrains from SIMS U-Pb zircon age. International Journal of Earth Science, v.101, p239-52.

Thakur, V.C., 1993, Geology of Western Himalaya. Pergamon, Oxford, $355 \mathrm{p}$.

Thanh, N.X., Sajeev, K., Itaya, T. and Windley, B.F., 2011, Multiple garnet growth in garnet-kyanite-staurolitegneiss, Pangong Metamorphic Complex, Ladakh Himalaya: new constraints on tectonic setting. Lithos, v.127, p552-563.

Valdiya, K.S., 1995, Proterozoic sedimentation and Pan-African geodynamic development of the Himalaya. Precambrian Research, v.74, p35-55.

Treloar, P.J., O’Brien, P.J., Parrish, R.R., and Khan, M.A., 2003, 
Exhumation of early Tertiary, coesite- bearing eclogites from the Pakistan Himalaya. Journal of Geological Society London, v.160, p367-376.

Vannay, J. C. and Hodges, K. V., 1996, Tectonometamorphic evolution of the Himalayan metamorphic core between the Annapurna and Dhaulagiri, central Nepal. Journal of Metamorphic Geology, v.14, p635 -656.

Vannay, J. C. and Grasemann, B., 1998, Inverted metamorphism in the High Himalaya of Himachal Pradesh (NW India): Phase equilibria versus thermobarometry, Schweiz. Mineralogy Petrogrophy Mitt., v.78, p107 - 132.

Vannay, J. C., and Grasemann, B., 2001, Himalayan inverted metamorphism and syn-convergence extension as a consequence of a general shear extrusion. Geological Magazine, v.138, p253276.

Vannay, J.C., Grasemann, B., Rahn, M., Frank, W., Carter, A., Baudraz, V. and Cosca, M., 2004, Miocene to Holocene exhumation of metamorphic crustal wedges in the NW Himalaya: Evidence for tectonic extrusion coupled to fluvial erosion. Tectonics, v. 23, p1-24.

Verma, P.K., 1989, The Himalayan Metamorphism. Geological Society Special Publication, v.43, p377-383.

Verma, P.K., 2003, The Himalayan Metamorphism and Generation of Melt.90th Sectional Presidential Address, 1-34.

Wallis, D., Phillips, R.J., Lloyd, G.E., 2013, Fault weakening across the frictional-viscous transition zone, Karakoram Fault Zone, NW Himalaya. Tectonics, v.35, p1227-1246, http://dx.doi.org/10.1002/ tect.20076.

Wallis, D., Phillips, R.J. and Lloyd, G.E., 2014, Evolution of the Eastern Karakoram Metamorphic Complex, Ladakh, NW India, and its relationship to magmatism and regional tectonics. Tectonophysics, v.626, p41-52. http://dx.doi.org/10.1016/ j.tecto.2014.03.023

Wang, J.M., Rubatto, D. and Jhang J.J., 2015, Timing of partial melting and cooling across the Greater Himalayan Crystalline Comlex (Nyalam, Central Himalaya): In-sequence thrusting and its implications. Journal Of Petrology, v.56, p1677-1702.

Warren, C.J., Singh, A.K., Roberts, N.M.W., Regis, D., 2014, Timing and conditions of peak metamorphism and cooling across the Zimithang Thrust, Arunachal Pradesh, India. Lithos, v.200-201, p94-110.

Webb, A. A G., Menold, C.A., Clarke A.C. and Hacker, B., 2013, Petrochronolgy of Himalayan ultra high-pressure eclogiets. Geology, v. 41(8), p835-838.

Wilke, F.D.H., O'Brien, P.J., Altenberger, U., Konrad- Schmolke, M., and Khan, M.A., 2010, Multi-stage reaction history of different eclogite types from the Pakistan Himalaya and implications for exhumation process. Lithos, v.114, p70-85, doi:10.1016/j.lithos.2009.07.015.

Whittington,A.G., 1996, Exhumation overrated at Nanga Parbat, northern Pakistan. Tectonophysics, v.260, p215-26

Yin, A., and Harrison, T.M., 2000, Geologic Evolution of the Himalayan-Tibetan Orogen: Annual Review of earth Sciences, v. 28, p211-280.

Yin, A., Dubey, C.S., Kelty, T.K., Gehrels, G.E., Chou, C.Y., Grove, M. and Lovera, O., 2006, Structural evolution of the Arunachal Himalaya and implications for asymmetric development of the Himalayan orogen. Current Science, v. 90, p195-206.

Yin, A., Dubey, C.S., Kelty, T.K., Webb, A.A.G., Harrison, T.M., Chou, C.Y., Célérier, J., 2010, Geologic correlation of the Himalayan orogen and Indian craton: part 2. Structural geology, geochronology, and tectonic evolution of the Eastern Himalaya. Geological Society of America Bulletin, v.122, p360-395. http:/ /dx.doi.org/10.1130/B26461.1.
Zeitler, P.K., Chamberlain, C.P., Smith, H.A., 1993, Synchronous anatexis, metamorphism, and rapid denudation at Nanga Parbat (Pakistan Himalaya). Geology, v. 21, p347-50.

Zhang, Y., Z., Replumaz, A., Wang, Guo Can, Leloup, P.H., Bernet, C.G.M, van der Beek, P., Paquette, J.L., Wang, A., Zhang, Ke Xin, Chevalier, Marie Luce, Li, Hai Bing, 2015, Timing and rate of exhumation along the Litang fault system, implication for fault reorganization in Southeast Tibet. Tectonics, v. 34, p1219-1243.

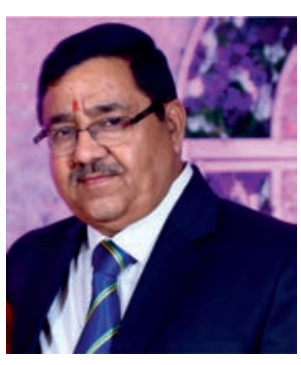

Prof. Naresh Chandra Pant works on microdomain characterization of geological material including the instrumentation associated with it. He has applied the technique to wide range of terrains including in Indian shield, East Antarctica and in the Himalaya. He is involved in planning of Indian Antarctic program nationally and with Scientific Committee on Antarctic Research (SCAR) internationally (2011-till date). He is a National Mineral awardee and fellow of Electron Microscope Society of India. He is the Deputy Chief Officer of SCAR currently. His PhD from Mohan Lal Sukhadia University Udaipur in 1990 was the first doctoral thesis out of Indian Scientific Expeditions to Antarctica. He has over 90 research publications and three edited books.

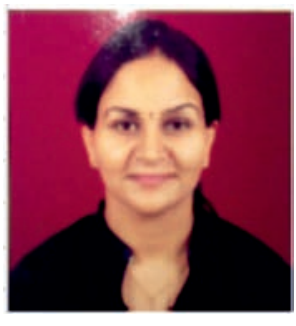

Dr. Preeti Singh working as a Research Scientist under MoES funded project 'Age constraint on the metamorphic evolution of the Trans Himalaya' in the Department of Geology, University of Delhi. PhD work includes the detailed studies of the UHPM rocks from the Tso Morari, NW Himalayas. Research work had main focus on understanding the geodynamic evolution of the Himalayas using tools of mineral chemistry and metamorphic petrology. Has more than 10 years of teaching experience.

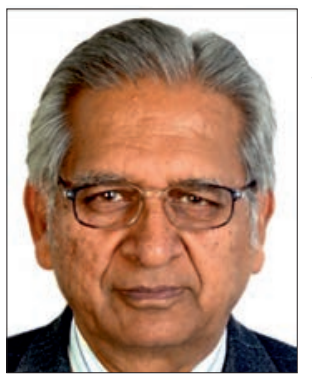

Prof. Arvind Kumar Jain is PhD in Geology from erstwhile University of Roorkee (now IIT Roorkee). He worked briefly as Scientist at Wadia Institute of Himalayan Geology, Dehradun, and then taught at the IIT Roorkee till 2007. He remained at the Institute as Emeritus Fellow till 2011. Prof. Jain was a Fellow, Alexander von Humboldt Foundation (1979 to 1981) Germany, Visiting Young Scientist London (1979), Visiting Scientist (1991) Sweden, Senior JSPS Fellow (2004) Japan, and a Fellow Indian National Science Academy (FNA). He has written/edited 5 books and more than 120 publications, including a book on the 'An Introduction to Structural Geology'. 